\title{
Gesty jako predyktor rozwoju komunikowania się u dzieci prawidłowo się rozwijających oraz z zaburzeniami rozwojowymi
}

AbSTRACT: Agnieszka Dłużniewska, Gesty jako predyktor rozwoju komunikowania się $u$ dzieci prawidłowo się rozwijajacych oraz z zaburzeniami rozwojowymi [Gestures as a predictor of the development of communication in children with normal development and developmental disorders]. Interdyscyplinarne Konteksty Pedagogiki Specjalnej, nr 14, Poznań 2016. Pp. 73-88. Adam Mickiewicz University Press. ISSN 2300-391X

Gestures and facial expressions appear in child communication before she/he is able to say the first word, and their qualitative and quantitative growth is considered an indicator of future language development.

The aims of this article is review of the research available in literature on the use of gestures in the communication process of children whose development is typically and children with developmental disorders.

There is an evidence that the differences in the development of gestures communication in children with typical and atypical development allow to predict potential language delays.

KEY WORDS: gestures, language development, children with developmental disorders

Gesty i mimika pojawiają się w komunikowaniu się dziecka zanim jest ono $w$ stanie wypowiedzieć pierwsze słowo, a ich jakościowy i ilościowy przyrost uznaje się za wskaźnik przyszłego roz- 
woju językowegoํ․ Co zatem badacze przedjęzykowych form komunikowania się dziecka rozumieją pod pojęciem gestów i czy rzeczywiście odgrywają one istotną rolę w kształtowaniu się języka?

Według Jana'y M. Iverson i D.J. Thal gesty są działaniami wykonywanymi z zamiarem komunikacji. Mogą być wyrażane za pomocą ruchów ramion, rąk i dłoni, mimiki oraz ruchów w obrębie całego ciała. Jak zakładają autorzy, aby gesty mogły być uznane za środek porozumiewania się, muszą być używane intencjonalnie². Pojawienie się pierwszych gestów obserwuje się w rozwoju dziecka około 7-12. miesiąca życia (dalej m.ż.). W literaturze ${ }^{3}$ wyróżnia się w ich obrębie trzy główne kategorie. Są to gesty deiktyczne, ikoniczne oraz konwencjonalne.

Gestów deiktycznych dziecko zaczyna używać między 7-9. a 12. m.ż. Odnoszą się one do konkretnych przedmiotów, osób lub miejsc, ale również stanowią odwołanie do zdarzeń. Interpretacji znaczenia tego typu gestów należy dokonywać jedynie w odniesieniu do ściśle określonego kontekstu. Wśród gestów deiktycznych można wyróżnić dwa rodzaje. Takie, które polegają na bezpośrednim kontakcie dziecka z przedmiotem lub opiekunem, przykładem

1 Zob. J.M. Iverson, S. Goldin-Meadow, Gesture paves the way for language development, "Psychological Science” 2005, nr 16(5), s. 367-371; N. Watt, A. Wetherby, S. Shumway, Prelinguistic predictors of language outcome at 3 years of age, "Journal of Speech, Language, and Hearing Research" 2006, nr 49, s. 1224-1237; M.L. Rowe, S. Goldin-Meadow, Early gesture selectively predicts later language learning, "Developmental Science" 2009, nr 12(1), s. 182-187; I.M. Zambrana, E. Ystrom, S. Schjølberg, F. Pons, Action imitation at $1 \frac{1}{2}$ years is better than pointing gesture in predicting late development of language production at 3 years of age, "Child Development" 2013, nr 84(2), s. 560-573.

2 Zob. E. Crais, D.D. Douglas, Ch.C. Campbell, The intersection of the development of gestures and intentionality, "Journal of Speech, Language, and Hearing Research" 2004, nr 47, s. 679.

${ }^{3}$ Zob. E.R. Crais, L.R. Watson, G.T. Baranek, Use of gesture development in profiling children's prelinguistic communication skills, "American Journal of Speech-Language Pathology" 2009, nr 18, s. 95-108; E. Sauer, S.C. Levine, S. Goldin-Meadow, Early gesture predicts language delay in children with pre- or perinatal brain lesions, “Child Development" 2010, nr 81(2), s. 528-539. 
może być podawanie przez dziecko zabawki lub odpychanie osoby opiekującej się nim, oraz te, które nie wymagają kontaktu i polegają na wskazywaniu lub zbliżaniu się do danego obiektu. W przypadku drugiego typu gestów często ostatecznym celem jest osiągnięcie fizycznego kontaktu z przedmiotem lub osobą. Pojawienie się pierwszego typu gestów można zaobserwować już około 7-9. m.ż. Są one realizowane m.in. poprzez dotykanie przedmiotu całą dłonią lub palcem wskazującym, podnoszenie przedmiotu do wysokości linii wzroku opiekuna, ale także wyciąganie rąk w kierunku towarzyszącej dziecku osoby dorosłej. Gesty, które nie wymagają bezpośredniego kontaktu, pojawiają się nieco później, około 10-12. m.ż. i świadczą o kolejnym etapie w rozwoju dziecka, polegającym na intencjonalnym posługiwaniu się gestem wskazującym ${ }^{4}$. Trudno jest z całą pewnością określić motywy użycia przez niespełna roczne dziecko gestu wskazującego jako elementu komunikowania się. Uważa się jednak, że dzieci najprawdopodobniej wykorzystują gesty do realizacji dwóch celów: aby nakłonić osobę dorosłą do wykonania jakiejś czynności lub zwrócić jej uwagę na określony element rzeczywistości (przedmiot lub czynność). W pierwszym przypadku gesty pełnią funkcję imperatywną, a w drugim deklaratywną5.

Inny podział gestów deiktycznych wyróżnia cztery ich rodzaje: sięganie, pokazywanie, podawanie i wskazywanie ${ }^{6}$.

Kolejną grupę stanowią gesty ikoniczne, powstające często z połączenia kilku gestów deiktycznych7. Dziecko zaczyna ich używać około 12. m.ż. w połączeniu z wokalizacją. Odnoszą się one do cech lub działania obiektu przez co nabierają znaczenia symbolicznego. Są realizowane za pomocą ruchów rąk, dłoni lub całego ciała i od-

${ }^{4}$ Zob. E.R. Crais, L.R. Watson, G.T. Baranek, op. cit.; E. Sauer, S.C. Levine, S. Goldin-Meadow, op. cit.

${ }^{5}$ Zob. U. Liszkowski, M. Carpenter, T. Striano, M. Tomasello, 12- and 18-montholds point to provide information for others, "Journal of Cognition and Development" 2006, nr 7(2), s. 173-187.

${ }^{6}$ Zob. E.R. Crais, D.D. Douglas, Ch.C. Campbell, op. cit., s. 681.

7 Zob. E.R. Crais, L.R. Watson, G.T. Baranek, op. cit., s. 96-97. 
grywają fundamentalną rolę $\mathrm{w}$ budowaniu komunikacji między dzieckiem a rodzicami ${ }^{8}$.

Gesty konwencjonalne natomiast, zdefiniowane kulturowo i używane $\mathrm{w}$ ramach danej społeczności, odnoszą się raczej do określonych działań i pojęć, nie zaś do przedmiotów. Do tego typu zachowań zalicza się np. machanie ręką na pożegnanie, przeczący lub potakujący gest głową, palec na ustach - prośba o ciszę.

Następnym etapem w rozwoju komunikowania się dziecka jest tworzenie przez nie kombinacji pierwszych słów i gestów. Jest to moment szczególnie ważny $\mathrm{z}$ punktu widzenia rozwoju języka. Badacze podkreślają, że takie połączenie odzwierciedla strukturę gramatyczną dwuczłonowych wypowiedzi i poprzedza pojawienie się dwuwyrazowych wypowiedzeń tworzonych w języku fonicznym ${ }^{9}$.

Wyniki longitudinalnych badań Jana'y M. Iverson i Susan Goldin-Meadow oraz Meredith L. Rowe, Susan Goldin-Meadow na grupie dzieci w wieku 10-24. m.ż. oraz na grupie dzieci w 18. m.ż. a następnie w $42 . \mathrm{m} . \dot{z}$. dowodzą, że:

1. Jesteśmy $\mathrm{w}$ stanie przewidzieć, jakie słowa pojawią się w słowniku dziecka, obserwując, które przedmioty, wskazuje ono około 3-4 miesiące wcześniej.

2. Rozwój komunikacji gestowej może odzwierciedlać potencjał dziecka do późniejszego opanowywania języka. Zasób słownika gestowego jest wskaźnikiem zasobu leksykalnego, którym dziecko prawdopodobnie będzie posługiwało się w przyszłości. Wskaźnikiem takim nie są natomiast $\mathrm{w}$ tym przypadku sekwencje typu gest + słowo, w których gest oznacza coś innego niż słowo, np. gest wskazujący filiżankę + słowo „mama”. Wskaźnikiem natomiast pojawienia się w mowie dziecka konstrukcji składniowych są sentencje gest + słowo. Wskaźnikiem nie jest w tym przypadku zasób słownika gestowego.

8 Zob. L. Acredolo, S. Goodwyn, Symbolic gesturing in normal infants, "Child Development" 1988, nr 59, s. 450-466; E.R. Crais, L.R. Watson, G.T. Baranek, op. cit., s. 96-97.

${ }_{9}^{9}$ Zob. J.M. Iverson, S. Goldin-Meadow, op. cit., s. 367. 
3. Gesty pojawiające się we wczesnym rozwoju dziecka lub ich brak mogą być wskaźnikiem potencjalnego opóźnienia w kształtowaniu się języka10.

Badaczki podkreślają jednak, że na podstawie obserwacji rozwoju komunikacji gestowej można określić jedynie potencjał dziecka do opanowywania poszczególnych aspektów języka, nie zaś predyspozycji do opanowywania języka w ogóle. Nie należy też zakładać, że z pewnością dojdzie do uaktywnienia się tego potencjału. Do tego potrzebna jest aktywność polegająca na uczestniczeniu w różnego rodzaju interakcjach, głównie z osobami dorosłymi.

Powyższe rozważania skłaniają do głębszej refleksji na temat roli i funkcji gestów w ewolucji procesu komunikowania się i rozwoju językowego dziecka.

Po pierwsze gesty tworzą swego rodzaju fundament, na którym tworzone są podstawy komunikacji. Gesty, których dziecko używa w kontakcie z osobą dorosłą, informują o jego gotowości do komunikowania się. W przypadku, gdy opiekun wykaże wrażliwość na tego rodzaju sygnały i dostosuje swój przekaz, starając się jednocześnie odczytać intencje dziecka, może dojść do nawiązania skutecznej interakcji, motywującej małego rozmówcę do podejmowania kolejnych wysiłków. Ogromną rolę będą tu zatem odgrywały epizody wspólnego zaangażowania ${ }^{11}$.

Po drugie gesty pełnią funkcję komunikatywną. Jerome Bruner wczesne akty komunikacyjne dziecka dzieli na trzy funkcjonalne kategorie: regulacja zachowania (np. odmowa, prośba o przedmiot), interakcje społeczne (np. podziękowanie, popisywanie się) oraz kierowanie wspólną uwagą (np. przyciąganie uwagi) ${ }^{12}$. Robert L.

${ }^{10}$ Zob. J.M. Iverson, S. Goldin-Meadow, op. cit.; M.L. Rowe, S. Goldin-Meadow, op. cit.

${ }^{11}$ Zob. H.R. Schaffer, Rozwój języka w kontekście, [w:] Dziecko w zabawie i świecie języka, red. A. Brzezińska i in., Zysk i S-ka, Poznań 1995, s. 164-192; M.L. Rowe, S. Goldin-Meadow, op. cit.; J.S. Bruner, Ontogeneza aktów mowy, [w:] Badania nad rozwojem jezyka dziecka, red. G.W. Shugar, M. Smoczyńska, PWN, Warszawa 1980, s. $483-513$.

${ }^{12}$ Zob. E.R. Crais, L.R. Watson, G.T. Baranek, op. cit., s. 97. 
Carpenter, Ann M. Mastergeorge oraz Truman E. Coggins wyróżnili siedem funkcji komunikacyjnych, które realizowały, obserwowane przez nich, dzieci w wieku od 8. m.ż. do 15. m.ż. Należały do nich: wyrażanie protestu (przed 8. m.ż), prośba o działanie (ok. 9. m.ż.), prośba o przedmiot (ok. 9. m.ż.), komentowanie działania (ok. 9,5. m.ż.), komentarze do przedmiotów (ok. 10,5. m.ż.), udzielanie odpowiedzi (ok. 15. m.ż.), prośba o informację (ok. 15. m.ż). Funkcje te były realizowane za pomocą trzech rodzajów środków: gestów, połączenia gestów i dźwięków oraz słów. Zachowania gestowe i gestowo-dźwiękowe dominowały w komunikowaniu się dzieci w wieku 8-12. m.ż. Po 10. m.ż. spadła częstotliwość używania samych gestów, ale wciąż, nawet u dzieci w 15. m.ż., obserwuje się używanie połączeń gestowo-dźwiękowych jako dominującego środka komunikowania się $e^{13}$.

Podobne badania przeprowadziły Elizabeth Crais, Diane Day Douglas oraz Cheryl Cox Campbell ${ }^{14}$. Obserwowały one zachowania komunikacyjne 20 dzieci wychowujących się w anglojęzycznych rodzinach. Z uwagi na fakt, że badaniami została objęta nieliczna grupa dzieci z określonego środowiska kulturowego, językowego oraz demograficznego, należy zachować ostrożność w wysuwaniu zbyt ogólnych wniosków.

Niewątpliwą zaletą tych badań jest fakt, że dzięki nim udało się zidentyfikować, skategoryzować oraz ustalić czas pojawienia się gestów używanych w komunikowaniu się przez dzieci w wieku między 6. a 20. m.ż. a także zaobserwować, że podczas realizacji dwóch wyodrębnionych przez Brunera funkcji (regulacja zachowania i nawiązywanie interakcji społecznych) gesty służące do ich realizacji zachowują omówioną wcześniej hierarchię. Początkowo dziecko posiłkuje się gestami deiktycznymi, a następnie ikonicznymi oraz konwencjonalnymi.

13 Zob. R.L. Carpenter, A.M. Mastergeorge, T.E. Coggins, The acquisition of communicative intentions in infants eight to fifteen months of age, "Language and Speech" 1983, 26(2), s. 101-116.

14 Zob. E. Crais, D.D. Douglas, Ch.C. Campbell, op. cit., s. 678-694. 
Crais, Douglas i Campbell podkreślają, że gestów deiktycznych używały wszystkie dzieci z badanej grupy, nawet jeśli były one stosowane tylko w jednym, określonym kontekście. W przypadku gestów ikonicznych oraz konwencjonalnych sytuacja przedstawiała się nieco inaczej. Zaobserwowano, że część dzieci w ogóle nie używała pewnych gestów. Jak się okazało, rodzice tych dzieci również nie wykorzystywali tego rodzaju gestów do komunikacji. W przypadku, gdy rodzice często używali w kontaktach ze swoimi dziećmi gestów ikonicznych oraz konwencjonalnych, ich dzieci także prezentowały szeroki repertuar tego rodzaju zachowań gestowych. Obserwacje te potwierdziły wcześniejsze spostrzeżenia Brendy Zinober i Margaret Martlew ${ }^{15}$, że w porównaniu do gestów deiktycznych, używanie przez dziecko gestów ikonicznych oraz konwencjonalnych jest podatniejsze na modelowanie środowiskowe związane z wykorzystywaniem ich przez opiekunów w kontaktach z dzieckiem. W związku z tym analiza komunikowania się gestowo-mimicznego powinna uwzględniać kontekst społeczny, w tym przypadku indywidualne różnice $\mathrm{w}$ kontaktach rodziców $\mathrm{z}$ dzieckiem. Należy też zaznaczyć, że dzieci zaczynają realizować dwie wymienione funkcje, wykorzystując gesty już około 6-7. m.ż.

Ciekawych wniosków dostarcza też analiza danych dotyczących realizacji trzeciej funkcji, dotyczącej kierowania wspólną uwagą. Funkcja ta pojawia się najpóźniej, bo ok. 8. m.ż. i jak zaznaczają autorki ${ }^{16}$, gesty mające na celu zwrócenie uwagi na konkretny przedmiot lub działanie są zazwyczaj poprzedzane innymi intencjonalnymi aktami, takimi jak: nawiązanie kontaktu wzrokowego, wokalizacja lub połączenie kontaktu wzrokowego i wokalizacji17.

Kolejną funkcją, jaką należy przypisać gestom w rozwoju komunikowania się dziecka, jest funkcja wyrażania sposobu myślenia i stanu poznawczego. Dziecko, wykorzystując przedmioty i gesty, informuje nas o sposobie przetwarzania informacji, przekazuje

15 Zob. Ibidem, s. 690.

${ }^{16}$ Ibidem.

17 Ibidem, s. 685-688. 
w ten sposób posiadaną wiedzę, której nie może jeszcze wyrazić za pomocą słów ${ }^{18}$. Badacze dostrzegają też w rozwoju gestów ikonicznych analogię do rozwoju języka, znajdując wspólne mechanizmy kształtowania się obu tych obszarów w pełnionej przez nie funkcji symbolicznej ${ }^{19}$.

Ostatnią i najważniejszą funkcją gestów jest otwieranie możliwości do rozwoju językowego poprzez wspólne z dorosłym ustalanie znaczeń ${ }^{20}$.

Jak zauważają badacze ${ }^{21}$, gesty ułatwiają i wspierają rozwój języka poprzez dostarczenie osobie dorosłej informacji dotyczącej gotowości dziecka do podjęcia kontaktu komunikacyjnego. Dorosły, który odczyta intencje dziecka, dostarcza mu informacji zwrotnych umożliwiających gromadzenie doświadczeń językowych prowadzących do opanowania systemu językowego. Gesty odgrywają także istotną rolę $\mathrm{w}$ kształtowaniu się umiejętności językowych z uwagi na to, że wykorzystują one wzrokowo-przestrzenne reprezentacje, które dla dziecka na wczesnym etapie rozwoju komunikowania się

18 Zob. S. Goldin-Meadow, Beyond words: The importance of gesture to researchers and learners, "Child Development" 2000, nr 71(1), s. 231-239; S. Goldin-Meadow, Gesture's role in the learning process, "Theory into Practice" 2004, nr 43(4), s. 314- 21; S. Goldin-Meadow, How gesture promotes learning throughout childhood, "Child Development Perspectives" 2009, nr 3(2), s. 106-111; L.L. Namy, N.S. Newcombe, More than just hand waving: Review of Hearing Gestures: How our hands help us think, "Journal of Cognition and Development" 2008, 9(2), s. 247-252; S.W. Cook, S. GoldinMeadow, The role of gesture in learning: Do children use their hands to change their minds?, "Journal of Cognition and Development" 2006, nr 7(2), s. 211-232; N.C. Capone, Tapping toddlers' evolving semantic representation via gesture, "Journal of Speech, Language, and Hearing Research" 2007, 50, s. 732-745.

19 Zob. L. Acredolo, S. Goodwyn, op. cit., s. 452-466.

20 Zob. M.A.K. Halliday, Uczenie się znaczeń, [w:] Badania nad rozwojem języka dziecka, red. G.W. Shugar, M. Smoczyńska, PWN, Warszawa 1980, s. 513-556; L. Paavola i in., Maternal sensitivity, infant co-operation and early linguistic development: Some predictive relations, "European Journal of Developmental Psychology" 2006, nr 3(1), s. 13-30; S. Goldin-Meadow i in., Young children use their hands to tell their mothers what to say, "Developmental Science" 2007, nr 10(6), s. 778-785; S. Goldin-Meadow, How gesture promotes learning..., s. 106-111.

21 Zob. J.M. Iverson, S. Goldin-Meadow, op. cit. 
mogą okazać się łatwiejsze do wyrażania pewnych znaczeń za pomocą gestu niż mowy. Posługiwanie się gestami jako przedjęzykowymi formami komunikowania się w znacznie mniejszym stopniu niż opanowywanie słów obciąża też pamięć dziecka. Dlatego też wykorzystywanie przez małe dzieci połączenia gestu i słowa, uznawane za zwiastun pojawienia się pierwszych dwuwyrazowych zdań, jest mniej angażujące poznawczo od użycia dwóch słów 22 .

W okresie wczesnego dzieciństwa sposób porozumiewania się dziecka ewoluuje i zaczyna ono preferować foniczny sposób wyrażania swoich myśli, potrzeb i uczuće ${ }^{23}$. Nie zmienia to jednak faktu, że gesty i mimika w dalszym ciągu stanowią integralną cześć procesu komunikowania się. Pełnią jednak inną niż dotychczas funkcję. Przestają być dominującym środkiem przekazu, a stają się elementem towarzyszącym językowi dźwiękowemu. Gesty, jakich używają dzieci między 2. a 5. r.ż., oprócz tego, że wzmacniają i podkreślają przekaz słowny, stanowią również swego rodzaju podstawę i jednocześnie wyraz ich rozwoju poznawczego. Wykorzystując gesty w zabawie, dzieci tworzą coraz bardziej złożone semantycznie przekazy pantomimiczne, co świadczy o ich umiejętności pozakontekstowego użycia symboli.

Jakościowy i ilościowy aspekt gestowo-mimicznego sposobu komunikowania się małego dziecka może być wyznacznikiem nieprawidłowości rozwojowych, nie tylko w zakresie funkcji językowych, ale również poznawczych. Aspekty, na które należy zwrócić uwagę, to przede wszystkim częstotliwość używania gestów, wykorzystywanie ich do komunikowania się, posługiwanie się gestami w połączeniu z kontaktem wzrokowym oraz wokalizacją, przejście od konkretnego do abstrakcyjnego użycia gestów, a następnie od gestów do słów ${ }^{24}$.

22 Ibidem.

${ }^{23}$ Zob. N.C. Capone, K.K. McGregor, Gesture development: a review for clinical and research practices, "Journal of Speech, Language, and Hearing Research" 2004, nr 47, s. 173-186.

24 Zob. N. Brady i in., Prelinguistic predictors of language growth in children with developmental disabilities, "Journal of Speech, Language, and Hearing Research" 2004, 
W artykule Gestures and word in early development children with Down Syndrome 25 wskazano na badania, które dotyczyły porównania umiejętności komunikacyjnych dzieci z prawidłowym rozwojem oraz dzieci z zespołem Downa (DS) w trzech aspektach: rozumienia mowy, produkowania dźwięków oraz używania gestów wskazują, że dzieci te wykazują dość istotne, w porównaniu do ich prawidłowo rozwijających się rówieśników, opóźnienia w każdym z wymienionych obszarów. W zakresie rozumienia mowy opóźnienie to wynosi około 14,3 miesiąca, w produkowania dźwięków mowy 13,4 miesiąca oraz używania gestów w komunikowaniu się 13,9 miesiąca. Badania wykazały ponadto, że dzieci z DS tworzą więcej niż ich rówieśnicy bez dysfunkcji symbolicznych gestów komunikacyjnych oznaczających pojęcia typu "poszedł", "gorący", "bądź cicho", "dobre”, gestów naśladujących działania dorosłych, np. podczas zabawy lalkami czy pluszowymi zwierzętami, a także gestów, które świadczą o zdolności do wykonywania przekształceń symbolicznych, np. udawanie, że kamienie są pokarmem lub patyczek łyżeczką itp. Badacze zwrócili uwagę na jeszcze jedną istotną różnicę. Otóż podczas gdy pierwsze i drugie stadium rozwoju komunikacji gestowo-fonicznej u dzieci prawidłowo rozwijających się i dzieci z zespołem Downa przebiegają podobnie (wyjaśnić w przypisie dolnym), o tyle $\mathrm{w}$ trzecim stadium $u$ dzieci $z$ DS, inaczej niż u ich rówieśników, następuje wzrost komunikacji gestowej z wykorzystaniem gestów symbolicznych. Autorzy tłumaczą to osiągnięciem wyższego stopnia socjalizacji i związaną z tym koniecznością

nr 47, s. 663-677; N.C. Capone, K.K. McGregor, op. cit.; E.R. Crais, L.R. Watson, G.T. Baranek, op. cit.; S. Shumway, A.M. Wetherby, Communicative acts of children with autism spectrum disorders in the second year of life, "Journal of Speech, Language, and Hearing Research" 2009, 52, s. 1139-1156; A.E. John, C.B. Mervis, Comprehension of the communicative intent behind pointing and gazing gestures by young children with Williams Syndrome or Down Syndrome, "Journal of Speech, Language, and Hearing Research" 2010, nr 53, s. 950-960.

25 Zob. M.C. Caselli i in., Gestures and word in early development children with Down Syndrome, “Journal of Speech, Language, and Hearing Research" 1998, nr 41, s. $1125-1134$. 
uruchomienia kompensacyjnej roli gestów w komunikowaniu się $\mathrm{z}$ uwagi na niski poziom komunikacji werbalnej.

Istotnych danych dostarczają także badania A.E. John, C.B. Mervis, których celem było porównanie zdolności przedszkolaków z zespołem Williamsa (WS) i zespołem Downa do rozpoznawania intencjonalnych i nieintencjonalnych komunikatów wyrażonych poprzez gesty i spojrzenia na tle umiejętności w zakresie percepcji i ekspresji językowej26.

Wyniki wskazują, że zarówno dzieci z zespołem Williamsa, jak i dzieci z zespołem Downa wykorzystują w komunikowaniu się wskazówki przekazywane im za pomocą gestów. Okazuje się natomiast, że dzieci zespołem Downa czynią to znacznie częściej (w 60\%), niż ich rówieśnicy z zespołem Williamsa (26,7\%). W przypadku dzieci z DS istnieje ponadto istotna statystycznie zależność pomiędzy zastosowaniem przez osobę dorosłą gestu i spojrzenia a wykonaniem zadania. W przypadku dzieci WS zależność ta nie jest natomiast istotna statystycznie.

Zatem zarówno dzieci z zespołem Downa, jak i zespołem Williamsa, podobnie, jak ich prawidłowo rozwijający się rówieśnicy, reagują na komunikaty gestowe, chociaż widoczne jest w tym zakresie poważne opóźnienie. Ważnym spostrzeżeniem jest także fakt, że pomimo iż dzieci z WS osiągnęły wyższy poziom rozumienia i ekspresji mowy niż dzieci z DS, to ich umiejętności w zakresie pragmatyki komunikowania są niższe. Należy się więc spodziewać, że istnieje większa szansa na prawidłową interpretację komunikatów gestowych przez dzieci z zespołem Downa niż przez ich rówieśników z zespołem Williamsa.

Kolejnych dowodów na istnienie różnic w zakresie komunikacji z użyciem gestów w odniesieniu do dzieci z atypowym przebiegiem rozwoju we wczesnym dzieciństwie dostarczają badania przeprowadzone przez Stacy Shumway i Amy M. Wetherby ${ }^{27}$. Badaczki skoncentrowały się na analizie zachowań komunikacyjnych

\footnotetext{
26 Zob. A.E. John, C.B. Mervis, op. cit.

27 Zob. S. Shumway, A.M. Wetherby, op. cit.
} 
z użyciem gestów przez dzieci, u których zostały stwierdzone zaburzenia ze spektrum autyzmu. Wyniki uzyskane przez wymienioną grupę porównano z wynikami uzyskanymi przez dzieci z zaburzeniami rozwojowymi $\mathrm{w}$ zakresie rozwoju języka oraz dzieci prawidłowo się rozwijających. $W$ analizie pod uwagę wzięto realizację funkcji komunikacyjnych w aspekcie regulacji zachowania, interakcji społecznych, dzielenia uwagi oraz rodzaj używanych gestów (deiktyczne, ikoniczne, konwencjonalne), wokalizacji i kontaktu wzrokowego. Uzyskane wyniki wskazują, że u dzieci z zaburzeniami ze spektrum autyzmu liczba aktów komunikacyjnych realizowanych za pomocą gestów na minutę jest znacznie niższa niż u dzieci z zaburzeniami rozwojowymi i dzieci prawidłowo rozwijających się. Najczęściej dzieci te używają gestów pełniących funkcję regulacji zachowania, a najrzadziej dzielenia uwagi. Jeśli chodzi o proporcje poszczególnych rodzajów gestów, to największy odsetek stanowią gesty deiktyczne, a najmniejszy ikoniczne polegające na inicjacji kontaktu bez użycia konkretnych przedmiotów tj. zbliżanie się do osoby, dotykanie jej lub przejawianie zachowań autoagresywnych w celu zwrócenia na siebie uwagi. Warto też zwrócić uwagę na różnice występujące między dziećmi z zaburzeniami w rozwoju języka a dziećmi prawidłowo funkcjonującymi. Otóż okazuje się, że pierwsza z wymienionych grup podczas komunikowania się używa mniej gestów na minutę, natomiast jeśli chodzi o funkcje, które te gesty pełnią $\mathrm{w}$ komunikowaniu się, to dzieci z zaburzeniami rozwoju językowego wykorzystują więcej gestów w funkcji regulacji zachowania oraz nawiązania interakcji społecznych, a mniej wskazujących na chęć dzielenia uwagi niż dzieci o prawidłowym rozwoju. Natomiast w przypadku rodzaju gestów częściej niż ich rówieśnicy bez dysfunkcji używają gestów deiktycznych i ikonicznych, a rzadziej konwencjonalnych. W odniesieniu do posługiwania się gestami złożonymi z działania i wokalizacji, działania i kontaktu wzrokowego czy też połączenia wszystkich rodzajów sygnałów zarówno dzieci ze spektrum autyzmu, jak i z zaburzeniami rozwoju językowego posługują się mniejszą liczbą gestów od swoich prawidłowo rozwijających się rówieśników. 
Rozumienie symboliki gestów przez dzieci z autyzmem było również przedmiotem badań Isabel M. Smith i Susan E. Bryson ${ }^{28}$. W tym przypadku porównaniu poddane zostały również trzy grupy badanych, z których jedną stanowiły dzieci z zaburzeniami ze spektrum autyzmu, drugą z deficytami rozwoju językowego, a trzecią dzieci o prawidłowym rozwoju. $W$ tym przypadku uzyskane wyniki również wskazywały na znacznie niższe kompetencje $\mathrm{w}$ posługiwaniu się gestami symbolicznymi przez dzieci $\mathrm{z}$ autyzmem niż te prezentowane przez dwie pozostałe grupy. Autorki podkreślają jednak, że $\mathrm{w}$ przypadku dzieci z autyzmem problemu nie stanowi samo naśladowanie gestów, ale przypisanie im znaczenia.

Związek między ilościowym i jakościowym aspektem posługiwania się gestami a kierunkiem rozwoju językowego potwierdzają także badania w grupie dzieci z SLI ${ }^{29}$ oraz uszkodzeniami prenatalnymi i okołoporodowymi uszkodzeniami mózgu ${ }^{30}$.

Podsumowując powyższe rozważania, nie sposób nie zauważyć, że wyniki dotychczasowych badań i obserwacji nad rozwojem komunikowania się dziecka wskazują na silny związek ewolucji zachowań przedjęzykowych z kierunkiem późniejszego rozwoju języka i komunikowania się. Rodzaj, struktura i różnorodność zachowań gestowych wykorzystywanych przez dziecko do komunikowania się we wczesnym okresie dzieciństwa mogą zatem okazać się pomocne $\mathrm{w}$ prognozowaniu przebiegu rozwoju językowego, a tym samym i poznawczego dziecka.

Warto jednak podkreślić, co potwierdzają różnice obserwowane $\mathrm{w}$ analizie wyników dotychczasowych badań, dotyczące głównie czasu pojawiania się określonego typu gestów, że podstawą do podejmowania wszelkich działań wspierających powinna stać się

28 Zob. I.M. Smith, S.E. Bryson, Gesture imitation in autism: II. Symbolic gestures and pantomimed object use, "Cognitive Neuropsychology" 2007, nr 24(7), s. 684-696.

${ }^{29}$ Zob. N. Botting, N. Riches, M. Gaynor, G. Morgan, Gesture production and comprehension in children with specific language impairment, "British Journal of Developmental Psychology" 2010, nr 28, s. 5I-69.

30 Zob. E. Sauer, S.C. Levine, S. Goldin-Meadow, op. cit. 
wnikliwa analiza czynników wpływających na indywidualny rozwój dziecka.

W przypadku dzieci, u których istnieje ryzyko wystąpienia dysfunkcji rozwojowych, ważna jest ocena najistotniejszych obszarów mogących ułatwić planowanie i wyznaczanie strategii terapii zaburzeń rozwoju mowy. Wiadomo, że kształtowanie się języka dziecka jest procesem długotrwałym, który potrzebuje solidnych podstaw w postaci umiejętności przedjęzykowych.

Oprócz czynników indywidualnych, takich jak: zachowania dźwiękowe, rozumienie słów, wykorzystywanie w zabawie zachowań symbolicznych, używanie do komunikowania się gestów, inicjowanie i odpowiadanie na zainicjowany kontakt, jako kluczowe dla późniejszego rozwoju języka, zarówno dzieci prawidłowo rozwijających się, jak i z dysfunkcjami rozwojowymi, uważa się uwarunkowania rodzinne (oddziaływania wychowawcze, predyspozycje genetyczne) $)^{31}$.

\section{Bibliografia}

Acredolo L., Goodwyn S., Symbolic gesturing in normal infants, "Child Development" 1988, 59.

Botting N., Riches N., Gaynor M., Morgan G., Gesture production and comprehension in children with specific language impairment, "British Journal of Developmental Psychology" 2010, 28.

Brady N., Marquis J., Fleming K., McLean L., Prelinguistic predictors of language growth in children with developmental disabilities, "Journal of Speech, Language, and Hearing Research" 2004, 47.

Bruner J.S. 1980, Ontogeneza aktów mowy, [w:] Badania nad rozwojem jezzyka dziecka, G. red. W. Shugar, M. Smoczyńska, PWN, Warszawa 1980.

Capone N.C. Tapping toddlers' evolving semantic representation via gesture, "Journal of Speech, Language, and Hearing Research" 2007, 50.

Capone N.C., McGregor K.K., Gesture development: a review for clinical and research practices, "Journal of Speech, Language, and Hearing Research" 2004, 47.

Carpenter R.L., Mastergeorge A.M., Coggins T.E. The acquisition of communicative intentions in infants eight to fifteen months of age, "Language and Speech" 1983, 26(2).

${ }^{31}$ Zob. E.R. Crais, L.R. Watson, G.T. Baranek, op. cit., s. 95-108. 
Caselli M.C. i in., Gestures and word in early development children with Down Syndrome, "Journal of Speech, Language, and Hearing Research" 1998, 41.

Cook S.W., Goldin-Meadow S., The role of gesture in learning: Do children use their hands to change their minds?, "Journal of Cognition and Development" 2006, 7(2).

Crais E., Douglas D.D., Campbell Ch.C., The intersection of the development of gestures and intentionality, "Journal of Speech, Language, and Hearing Research" 2004, 47.

Crais E.R., WatsonL. R., Baranek G.T., Use of gesture development in profiling children's prelinguistic communication skills, "American Journal of Speech-Language Pathology" 2009, 18.

Goldin-Meadow S., Beyond words: The importance of gesture to researchers and learners, "Child Development" 2000, 71(1).

Goldin-Meadow S., Gesture's role in the learning process, "Theory into Practice" 2004, $43(4)$.

Goldin-Meadow S., How gesture promotes learning throughout childhood, "Child Development Perspectives" 2009, 3(2).

Goldin-Meadow S., Goodrich W., Sauer E., Iverson J., Young children use their hands to tell their mothers what to say, "Developmental Science" 2007, 10(6).

Halliday M.A.K., Uczenie się znaczeń, [w:] Badania nad rozwojem języka dziecka, red. G.W. Shugar, M. Smoczyńska, PWN, Warszawa 1980.

Iverson J.M., Goldin-Meadow S., Gesture paves the way for language development, „Psychological Science" 2005, 16(5).

John A.E., Mervis C.B., Comprehension of the communicative intent behind pointing and gazing gestures by young children with Williams Syndrome or Down Syndrome, "Journal of Speech, Language, and Hearing Research" 2010, 53.

Liszkowski U., Carpenter M., Striano T., Tomasello M., 12- and 18-month-olds point to provide information for others, "Journal of Cognition and Development" 2006, 7(2).

Namy L.L., Newcombe N.S., More than just hand waving: Review of Hearing Gestures: How our hands help us think, "Journal of Cognition and Development" 2008, 9(2).

Paavola L., Kemppinen K., Kumpulainen K., Moilanen I., Ebeling H., Maternal sensitivity, infant co-operation and early linguistic development: Some predictive relations, “European Journal of Developmental Psychology" 2006, 3(1).

Rowe M.L., Goldin-Meadow S., Early gesture selectively predicts later language learning, "Developmental Science" 2009, 12 (1).

Sauer E., Levine S.C., Goldin-Meadow S., Early gesture predicts language delay in children with pre- or perinatal brain lesions, "Child Development" 2010, 81(2).

Smith I.M., Bryson S.E., Gesture imitation in autism: II. Symbolic gestures andpantomimed object use, "Cognitive Neuropsychology" 2007, 24(7).

Schaffer H.R., Rozwój języka w kontekście, [w:] Dziecko w zabawie i świecie języka, red. A. Brzezińska i in., Zysk i S-ka, Poznań 1995. 
Shumway S., Wetherby A.M., Communicative acts of children with autism spectrum disorders in the second year of life, "Journal of Speech, Language, and Hearing Research" 2009, 52.

Watt N., Wetherby A., Shumway S., Prelinguistic predictors of language outcome at 3 years of age, "Journal of Speech, Language, and Hearing Research" 2006, 49.

Zambrana I.M., Ystrom E., Schjølberg S., Pons F., Action imitation at 11/2 years is better than pointing gesture in predicting late development of language production at 3 years of age, "Child Development" 2013, 84(2). 